\title{
$\mathrm{Mg}(\mathrm{OH})_{2}$ の熱分解における HF 添加の影響
}

\author{
真保満雄 ·大矢 豊 - 中川善兵衛 $\cdot$ 浜野健 也* \\ ( 東京工業大学工業材料研究所, 227 横浜市緑区長津田町 4259 \\ $(*$ 神奈川大学工学部工業化学科, 221 横浜市神奈川区六角橋 3-27-1)
}

\section{Effect of HF Addition on Decomposition of $\mathrm{Mg}(\mathrm{OH})_{2}$}

\author{
Mitsuo SHIMBO, Zenbe-e NAKAGAWA, Yutaka OHYA and Kenya HAMANO* \\ Research Laboratory of Engineering Materials, Tokyo Institute of Technology, 4259, Nagatsuta, Midori-ku, \\ Yokohama-shi 227 \\ *Faculty of Engineering, Kanagawa University, 3-27-1, Rokkakubashi, Kanagawa-ku, Yokohama-shi \\ 221
}

\begin{abstract}
The effect of $H F$ on the decomposition of brucite was studied by differential thermal analysis (DTA) and X-ray powder diffraction (XRD). HF was added to brucite by addition of fluoride or by treatment with hydrofluoric acid solutions. In fluoride addition, $\mathrm{AlF}_{3}$ was more effective in retarding the decomposition of brucite than $\mathrm{MgF} \mathrm{F}_{2}$. HF gas was formed by the hydrolysis of fluoride and then sorbed on the surface of brucite. The endothermic peak of brucite shifted to high temperature from several to about 40 degrees with increasing $\mathrm{AlF}_{3}$ content from 0.5 to $5 \mathrm{~mol} \%$. Similarly, the endothermic peak of brucite treated with hydrofluoric acid solution also shifted to high temperature, about $70^{\circ} \mathrm{C}$ for the specimen treated with 0.15 HF (molar ratio of HF vs. brucite). The retardation of decomposition was due to the chemisorption of HF on the edge of brucite which would decompose from the edge.

[Received January 6, 1989; Accepted March 16, 1989]
\end{abstract}

Key-words : $\mathrm{Mg}(\mathrm{OH})_{2}$, Decomposition, Fluorine addition, DTA, Chemisorption, HF

\section{1. 緒言}

マグネシアセラミックスの安価な焼成原料として，水 酸化マグネシウム $\mathrm{Mg}(\mathrm{OH})_{2}$ の仮焼により得られる $\mathrm{MgO}$ が広く用いられている。この $\mathrm{MgO}$ の焼結性を改 善する目的で添加剤の研究が行われているが, その多く のものは陽イオンの効果についてであり, 陰イオンの効 果に留意したものは少ないようである，陰イオンである 八ロゲン化物イオンが $\mathrm{Mg}(\mathrm{OH})_{2}$ の仮焼に及ぼす影響に ついて, 幾つかの報告がある。浜野らは各種化合物の添 加の影響を調べて，八ロゲン化物である $\mathrm{CaF}_{2}, \mathrm{CaCl}_{2}{ }^{11}$ 及び $\mathrm{MgCl}_{2}{ }^{2)}$ は, $900^{\circ} \mathrm{C}$ の仮焼で $\mathrm{MgO}$ の結晶成長を促 進する効果のあることを報告している。池上ら ${ }^{3)}$ は $\mathrm{Mg}$ $(\mathrm{OH})_{2}$ 粉末を塩酸又はフッ酸溶液で処理したものの仮 焼について, $\mathrm{Cl}^{-}$は $\mathrm{MgO}$ 粉末の粒成長を助けるが, $\mathrm{F}^{-}$は $900^{\circ} \mathrm{C}$ 以下では粒成長を抑制し， $1000^{\circ} \mathrm{C}$ 以上で は促進することを報告している.

ハロゲン化物の影響を $\mathrm{Mg}(\mathrm{OH})_{2}$ の分解過程に限って みると, 塩素に関しては幾つかの報告がなされてい $ろ^{2), 4)}$. 浜野らは $\mathrm{Mg}(\mathrm{OH})_{2}$ 粒子に $\mathrm{MgCl}_{2}$ を添加した場 合, 分解が粒子の各所から進行して, $\mathrm{Mg}(\mathrm{OH})_{2}$ の分解 が促進されると説明している4). しかし，フッ素の効果 についてはまだ明らかにされていない部分が多い.

本研究では $\mathrm{Mg}(\mathrm{OH})_{2}$ の分解過程に及ぼす $\mathrm{HF}$ の影響 を, $\mathrm{MgF}_{2}$ 又は $\mathrm{AlF}_{3}$ を添加した場合と, フッ酸溶液処 理して直接 $\mathrm{HF}$ を作用させた場合の双方について検討
を行った. なお, 前者においてフッ素はフッ化物の加水 分解により HF ガスとして供給されるため, その分解 過程もあわせて調べた。

\section{2. 実験方法}

$\mathrm{Mg}(\mathrm{OH})_{2}$ は岩谷化学製で $\mathrm{MgO}$ として純度 99.9 wt \%のものを使用した.この $\mathrm{Mg}(\mathrm{OH})_{2}$ は約 $0.5 \mu \mathrm{m}$ の六 角板状結晶で, 比表面積は $4.55 \mathrm{~m}^{2} / \mathrm{g}$ である.X線回折 の結果, ブルーサイトのほかに微量のペリクレースと $\alpha$-シュウ酸マグネシウム二水塩を含んでいる. 添加する フッ化物は, 日亜化学製 $\mathrm{MgF}_{2}$, 日本軽金属製 $\mathrm{AlF}_{3}$ を 使用した. $\mathrm{MgF}_{2}$ は粒径が $2 \mu \mathrm{m}, \mathrm{AlF}_{3}$ は数十 $\mathrm{nm}$ の一 次粒子が約 $1 \mu \mathrm{m}$ の集合塊を形成したものである. $\mathrm{AlF}_{3}$ にはメーカー值で $2.2 \mathrm{wt} \%$ の含水量を持っている. フッ化物の添加は $\mathrm{MgF}_{2}$ 又は $\mathrm{AlF}_{3}$ を $\mathrm{Mg}(\mathrm{OH})_{2}$ に対し て $2 \mathrm{~mol} \%$ 加え, 4 時間エ夕ノール湿式混合することに より行った.フッ酸処理をする場合は $\mathrm{Mg}(\mathrm{OH})_{2}$ をエ夕 ノール中に分散させ, マグネチックスターラーでかくは んしながら, エタノールで希釈したフッ酸を $\mathrm{Mg}(\mathrm{OH})_{2}$ に対してモル比で $10^{-3} \sim 1.0$ になるよう加えて行った. これを 2 分間かくはんした後, 沪過して乾燥させたもの をフッ酸処理試料とした. また, 比較のためにフッ酸を 用いずに処理した試料も作製した。

試料の加熱は $6^{\circ} \mathrm{C} / \mathrm{min}$ の速さで $300^{\circ} \sim 700^{\circ} \mathrm{C}$ の所定 温度まで昇温した後, 直ちに急冷することにより行った。 
結晶相の同定, 定量及び結晶子径の測定を黒鉛分光結晶 で単色化した $\mathrm{Cu} K \alpha$ 線を用いた粉末 X 線回折装置（理 学電機製 RU-200 型) で行った. ペリクレースの結晶 子径は電融マグネシア粉末を標準としてペリクレースの 420 回折線から求めた。フッ酸処理した試料に残存する $\mathrm{MgF}_{2}$ の定量を $\mathrm{X}$ 線回折で, フッ素含有量はフッ素を蒸 留分離してアリザリンコンプレクソン吸光光度法により 求めた. 試料の形態観察は日本電子製透過型電子顕微鏡 (TEM) JEM-2000 EX 型（加速電圧 $200 \mathrm{kV}$ ) で行っ た. 試料表面での $\mathrm{F}^{-}, \mathrm{Al}^{3+}, \mathrm{Mg}^{2+}$ の結合状態を CsI 錠剤法により IR で調べた。

\section{3. 結果と考察}

\section{1 フッ化物の分解に対する水蒸気の影響}

フッ化物の加水分解には, $\mathrm{Mg}(\mathrm{OH})_{2}$ の分解における 環境亡類似するように $\mathrm{Mg}(\mathrm{OH})_{2}$ の熱分解により発生す る水蒸気を用い, フッ化物は $\mathrm{Mg}(\mathrm{OH})_{2}$ に対して $2 \mathrm{~mol}$ \%となるようにした. 試料の配置を図 1 に示した. $\mathrm{Mg}$ $(\mathrm{OH})_{2}$ を敷いたアルミナるつぼ中に, $\mathrm{MgF}_{2}$ 又は $\mathrm{AlF}_{3}$ $0.4 \mathrm{~g}$ を入れた白金皿を離して置き，アルミナ製のふた をした.このるつぼを電気炉で所定の温度まで加熱した 後, 直ちに取り出し, フッ化物試料の重量減少と結晶相 の測定を行った. 温度は $\mathrm{Mg}(\mathrm{OH})_{2}$ の分解温度付近の $400^{\circ} \mathrm{C}$, 分解後の $500^{\circ} \mathrm{C}$, 更に高温の $700^{\circ} \mathrm{C}$ を選んだ. 表 1 に $\mathrm{Mg}(\mathrm{OH})_{2}$ を共存したときとしなかったときの

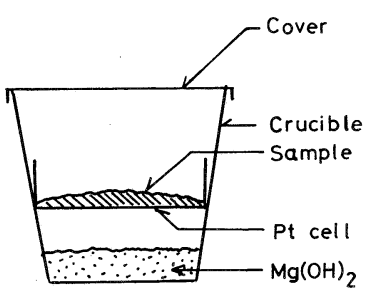

Fig. 1. Schematic diagram of sample positions in the decomposition experiment of fluoride.

Table 1. Weight loss of fluoride at various temperatures.

\begin{tabular}{|c|c|c|c|c|c|c|}
\hline \multirow{2}{*}{$\begin{array}{l}\text { Temp } \\
\left({ }^{\circ} \mathrm{C}\right)\end{array}$} & \multicolumn{3}{|c|}{$\mathrm{MgF}_{2}$} & \multicolumn{3}{|c|}{$\mathrm{AlF}_{3}$} \\
\hline & 1 & 2 & B & 1 & 2 & B \\
\hline 400 & 0.1 & 0.1 & 3.3 & 5.6 & 6.0 & 3.4 \\
\hline 500 & 0.2 & 0.4 & 26.9 & 6.3 & 15.2 & 24.3 \\
\hline 700 & 0.7 & 0.6 & 31.1 & 8.2 & 38.8 & 28.7 \\
\hline
\end{tabular}

1 : fluoride on $1 y$

2 : fluoride affected by water vapor from brucite

B : weight loss of brucite used in the experiment 2
フッ化物の各重量減少と前者における $\mathrm{Mg}(\mathrm{OH})_{2}$ の重量 減少を示した. $\mathrm{MgF}_{2}$ の場合,重量減少は少なく, $\mathrm{Mg}(\mathrm{OH})$ からの水蒸気の影響を受けないものとほとんど同じ変化 を示した。結晶相はいずれも $\mathrm{MgF}_{2}$ のみであった。 $\mathrm{MgF}_{2}$ の蒸気圧は $1000^{\circ} \mathrm{C}$ で約 $10^{-6} \mathrm{~atm}^{5)}$ であり, $700^{\circ} \mathrm{C}$ 以下の温度において蒸発の影響は無視しうると考えられ る.したがって, $\mathrm{MgF}_{2}$ の分解による $\mathrm{MgO}$ の生成率は, $\mathrm{MgF}_{2}$ の重量減少から求められる. $\mathrm{Mg}(\mathrm{OH})_{2}$ の分解の 影響下において, $\mathrm{MgO}$ の生成率は $400^{\circ} \mathrm{C}$ で 0.16 wt \% , $500^{\circ} \mathrm{C}$ では $0.68 \mathrm{wt} \%$ となった。X線の回折条件，45 $\mathrm{kV}, 120 \mathrm{~mA}$, スリット系 $1^{\circ}-1^{\circ}-0.15-0.3$ での $500^{\circ} \mathrm{C}$ で 仮焼したペリクレースの検出限界は約 0.2 wt \% であっ たが， $500^{\circ} \mathrm{C}$ 仮焼物にペリクレースが認められなかった ことは, $\mathrm{MgF}_{2}$ の分解で生成する $\mathrm{MgO}$ がアモルファス であるか，あるいは非常に結晶性の憲いものであると考 えられる。

一方, $\mathrm{AlF}_{3}$ の場合は, $500^{\circ} \mathrm{C}$ 以上で水蒸気の影響が 著しく, $\mathrm{AlF}_{3}$ 単味のものよりも急速に減量が進んでい る. 結晶相はどの温度においても $\alpha-\mathrm{AlF}_{3}$ のみであり, IR の結果も $\alpha-\mathrm{AlF}_{3}$ に関する吸収帯だけが認められた。 $\alpha-\mathrm{AlF}_{3}$ の分解による $\alpha-\mathrm{Al}_{2} \mathrm{O}_{3}$ の生成温度は $500^{\circ} \sim 760^{\circ} \mathrm{C}$ 付近 ${ }^{6), 7)}$ と報告されているので, この重量減少が $\mathrm{AlF}_{3}$ の分解によるものならば，分解生成物は $\mathrm{MgF}_{2}$ の場合 と同様，アモルファスであるかあるいは結晶性が悪いた めに, X線回折では検出されなかったものと考えられる.

表 1 より, フッ化物の分解は, 大気中で $\mathrm{MgF}_{2}$ より $\mathrm{AlF}_{3}$ の方が多い.これは, $\mathrm{AlF}_{3} に$ 含まれていた水分の ためで,この水分の蒸発によって $\mathrm{AlF}_{3}$ の加水分解が促 進されたものと思われる. また，これらの分解に伴って $\mathrm{HF}$ ガスが発生していると考えられる.

\section{2 フッ化物を添加した $\mathrm{Mg}(\mathrm{OH})_{2}$ の分解過程}

フッ化物添加試料の DTA の結果を図 2 に示した。

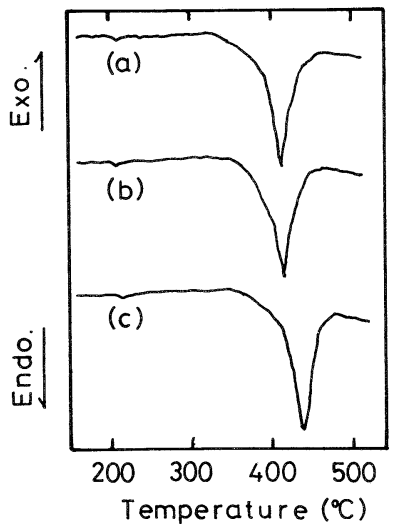

Fig. 2. DTA curves of $\mathrm{Mg}(\mathrm{OH})_{2}$ with and without fluoride.
(a) No addition, (b) $\mathrm{MgF}_{2} 2 \mathrm{~mol} \%$ addition,
(c) $\mathrm{AlF}_{3} 2 \mathrm{~mol} \%$ addition 
(b)

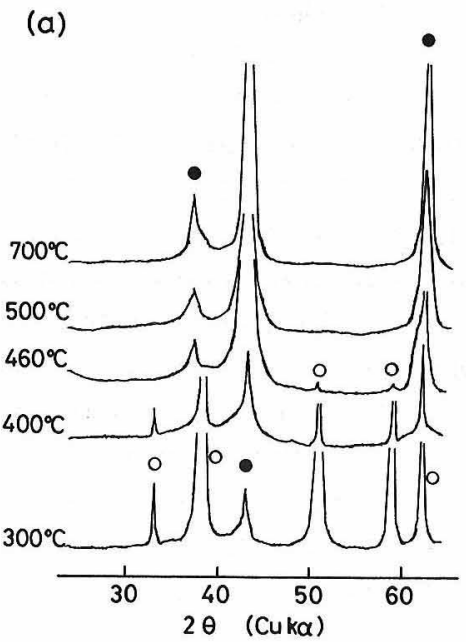

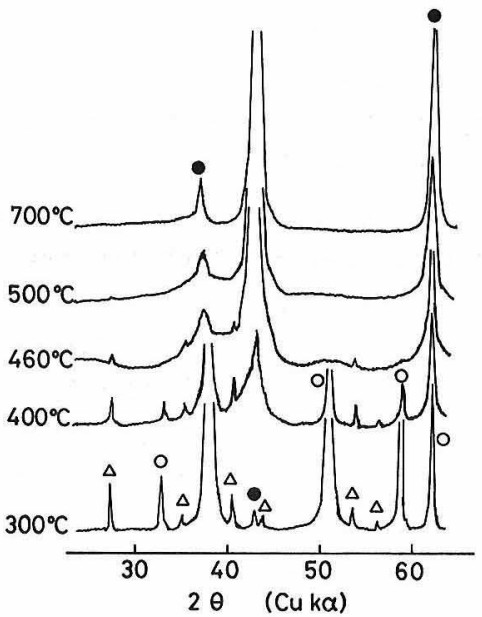

(c)

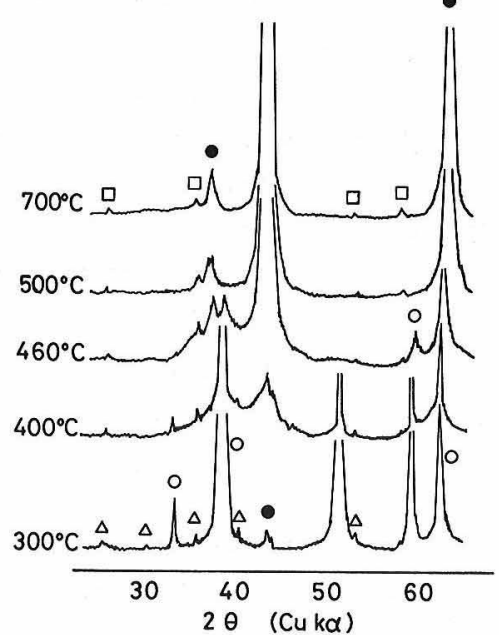

Fig.3. X-ray diffraction patterns of $\mathrm{Mg}(\mathrm{OH})_{2}$ with and without fluoride at various temperatures.

(a) No addition, (b) $\mathrm{MgF}_{2} 2 \mathrm{~mol} \%$ addition, (c) $\mathrm{AlF}_{3} 2 \mathrm{~mol} \%$ addition

$\mathrm{O}: \mathrm{Mg}(\mathrm{OH})_{2}, \quad \mathrm{MgO}, \Delta: \mathrm{MgF}_{2}, \boldsymbol{\Delta}: \gamma-\mathrm{AlF}_{3}, \quad \square: \alpha-\mathrm{Al}_{2} \mathrm{O}_{3}$

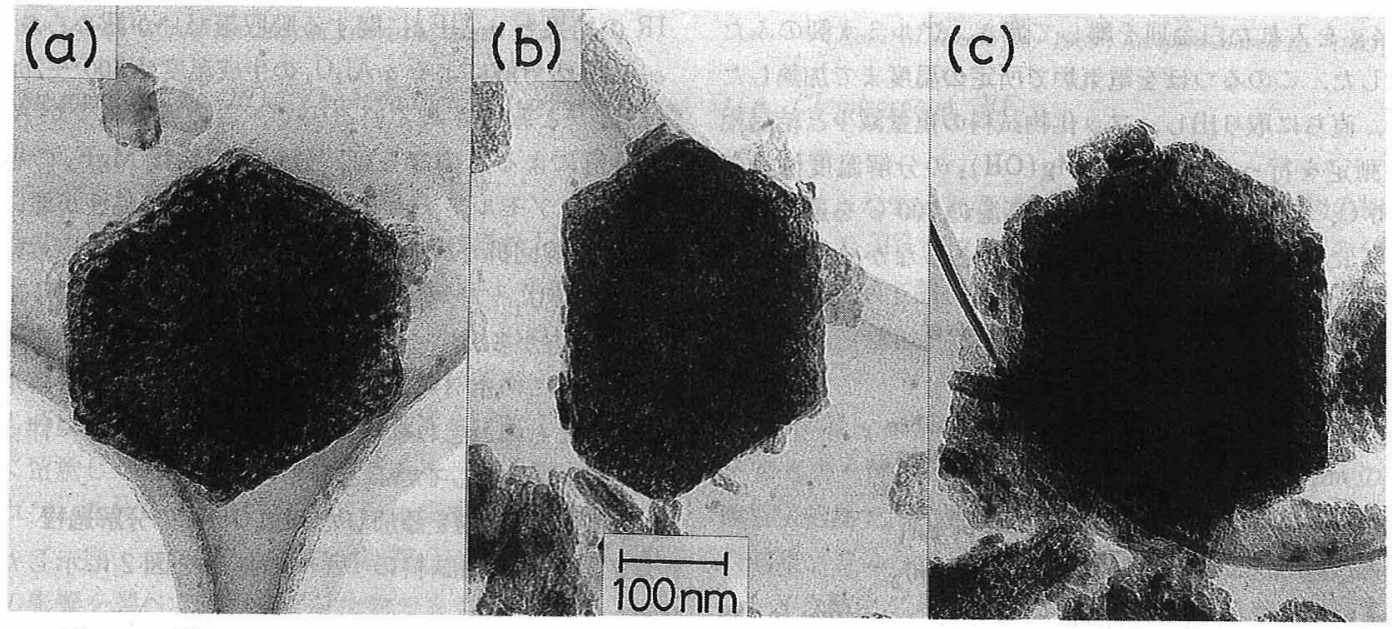

Fig. 4. TEM photographs of $\mathrm{MgO}$ dehydrated from $\mathrm{Mg}(\mathrm{OH})_{2}$ with and without fluoride $\left(700^{\circ} \mathrm{C}\right.$, quenching).

(a) No addition, (b) $\mathrm{MgF}_{2} 2 \mathrm{~mol} \%$ addition, (c) $\mathrm{AlF}_{3} 2 \mathrm{~mol} \%$ addition

$\mathrm{Mg}(\mathrm{OH})_{2}$ 単味の分解の吸熱ピークの頂点は $416^{\circ} \mathrm{C}$ であ るのに対して, $\mathrm{MgF}_{2}$ 添加では $419^{\circ} \mathrm{C}, \mathrm{AlF}_{3}$ 添加では $439^{\circ} \mathrm{C}$ といずれも高温側へ移動している. 加熱過程の各 試料の結晶相変化を調べた結果, 図了に示したX線粉末 回折パターンが得られた.いずれの試料も $300^{\circ}$ から $400^{\circ} \mathrm{C}$ で $\mathrm{MgO}$ の回折線強度が増加しており, 分解の進 んでいることがわかる. $460^{\circ} \mathrm{C}$ では, 無添加及び $\mathrm{MgF}_{2}$ 添加試料において $\mathrm{Mg}(\mathrm{OH})_{2}$ は認められなくなるのに対 して, $\mathrm{AlF}_{3}$ を添加したものでは $\mathrm{Mg}(\mathrm{OH})_{2}$ の微弱な回 折線が認められ，分解の遅れていることがわかった．こ の回折線は $500^{\circ} \mathrm{C}$ で検出されなくなり, 代わって微量 のコランダムが認められた. 前節の $\mathrm{AlF}_{3}$ 単味の分解で
はコランダムは認められていないので, $\mathrm{AlF}_{3}$ の分解で 生成する, アモルファス又は結晶度の悪いアルミナから のコランダム化が, 共存する $\mathrm{MgO}$ の触媒効果により促 進されたものではないかと思われる.

各温度での加熱物の TEM 観察を行った結果, $\mathrm{Mg}$ $(\mathrm{OH})_{2}$ の分解時の形態上の相違は認められず，生成す る $\mathrm{MgO}$ 粒子の集合体はいずれも $\mathrm{Mg}(\mathrm{OH})_{2}$ の仮像を形 成していた．図 4 は $700^{\circ} \mathrm{C}$ まで加熱した試料であるが, $\mathrm{MgO}$ の一次粒子の大きさは無添加で $15 \sim 20 \mathrm{~nm}$, $\mathrm{MgF}_{2}$ 及び $\mathrm{AlF}_{3}$ 添加では 10 15 nm とフッ化物を添加 した場合にはやや小さかった。

フッ化物の添加量の影響については, 添加量を 0.5 か 
ら $5 \mathrm{~mol} \%$ まで変えた試料の DTA を測定して， Mg $(\mathrm{OH})_{2}$ の分解に伴う吸熱ピークの移動を調べた. その 結果, $\mathrm{MgF}_{2}$ では添加量が $5 \mathrm{~mol} \%$ になってもピーク は $6^{\circ} \mathrm{C}$ 高温側に移動するだけであった。これに対して $\mathrm{AlF}_{3}$ 添加の場合は, $0.5 \mathrm{~mol} \%$ 添加の $425^{\circ} \mathrm{C}$ 加ら 5 mol \% 添加の $457^{\circ} \mathrm{C}$ まで, 添加量が増すのに伴い, ピー クが高温側へ移動した．以上の結果より，フッ化物の添 加は $\mathrm{Mg}(\mathrm{OH})_{2}$ の分解過程で試料の形態にはほとんど影 響を与えないが，分解温度を高温側へ移動させる効果の あることがわかった。

\section{3 フッ酸処理した $\mathrm{Mg}(\mathrm{OH})_{2}$ の分解過程}

$\mathrm{Mg}(\mathrm{OH})_{2}$ 粉末をフッ酸で処理した試料の結晶相を表 2 に示した. 未処理試料と溶液中のフッ酸濃度が薄い場 合，すなわち $\mathrm{Mg}(\mathrm{OH})_{2}$ とのモル化が $10^{-3}$ (以後 $10^{-3}$ HF などと略す) の試料では, 主結晶相がブルーサイト でこのほか微量のシュウ酸マグネシウムとペリクレース が認められた。 $0.01 ， 0.05 \mathrm{HF}$ はブルーサイトのみで, このフッ酸濃度では処理時間を 1 時間まで延ばしても $\mathrm{MgF}_{2}$ は認められなかった。また，0.15 HFにおいては 微量の $\mathrm{MgF}_{2}$ が認められるようになり，1.0 HF では

Table 2. Crystalline phases and fluorine content in brucite specimen treated with $\mathrm{HF}$ solution.

\begin{tabular}{llc}
\hline $\begin{array}{l}\text { Treatment } \\
\text { conditions }\end{array}$ & $\begin{array}{l}\text { Crystalline } \\
\text { phases }\end{array}$ & $\begin{array}{l}\text { Remained } \\
\text { fluorine(wt\%) }\end{array}$ \\
\hline Blank & B,MO*, P** & 0 \\
& & \\
$1 \times 10^{-3}$ HF & B,MO**, P** & 0.01 \\
$1 \times 10^{-2}$ & $\mathrm{~B}$ & 0.60 \\
$5 \times 10^{-2}$ & $\mathrm{~B}$ & 1.78 \\
0.15 & $\mathrm{~B}, \mathrm{MgF}_{2}{ }^{* *}$ & 5.77 \\
1.0 & $\mathrm{MgF}_{2}, \mathrm{~B}$ & \\
\hline
\end{tabular}

$\begin{aligned} \text { B : Brucite } & * * \text { : trace peak } \\ \text { P : Periclase } & * \text { : weak peak } \\ \text { MO }: \text { Magnesium oxalate } & \end{aligned}$

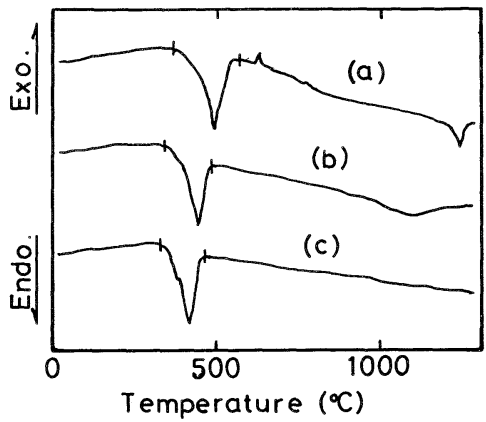

Fig.5. DTA curves of $\mathrm{Mg}(\mathrm{OH})_{2}$ treated with $\mathrm{HF}$ solutions.
(a) $0.15 \mathrm{HF}$, (b) $0.01 \mathrm{HF}$, (c) No addition

$\mathrm{MgF}_{2}$ が主結晶相となった．以上の結果より，処理の際 に $\mathrm{Mg}(\mathrm{OH})_{2}$ の一部と $\mathrm{HF}$ が反応していることがわかっ た。

主な試料の DTA の結果を図 5 に示す.フッ酸未処理 試料の $\mathrm{Mg}(\mathrm{OH})_{2}$ の分解の吸熱ピークは $420^{\circ} \mathrm{C}$ であり, 原料粉末のピークに比べ $4^{\circ} \mathrm{C}$ 高くなった.この結果は, エタノール処理の沪過の際に微細な粒子が流出したた め, 分解温度が高温側へ移行したものと思われる.フッ 酸処理試料では $0.15 \mathrm{HF}$ が $487^{\circ} \mathrm{C}$ と末処理に比べて約 $70^{\circ} \mathrm{C}$ も高い值を示した.この試料では $\mathrm{Mg}(\mathrm{OH})_{2}$ の分 解ピークのほかに, $625^{\circ} \mathrm{C}$ に発熱ピークが, $1240^{\circ} \mathrm{C}$ 付 近に吸熱ピークが見られた。これらのピーク直後の $650^{\circ}$ 及び $1260^{\circ} \mathrm{C}$ で急冷した試料の結晶相は, いずれも

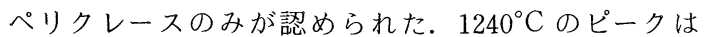
$\mathrm{MgO}$ と $\mathrm{MgF}_{2}$ の共融点の温度 $1228^{\circ} \mathrm{C}^{8)}$ とほぼ等しいこ とから，液相の生成によるものと考えられる．また， $650^{\circ} \mathrm{C}$ のピークの原因については不明である.

$0.15 \mathrm{HF}$ のフッ素含有量は, $\mathrm{X}$ 線回折より求めた $\mathrm{MgF}_{2}$ 含有率から計算すると約 $2.2 \mathrm{wt} \%$ であったが, 化学分析の結果では $5.77 \mathrm{wt} \%$ となり, 前者の約 2.5 倍であった。この差は後で述べるように, ブルーサイト 表面に吸着している HF の存在を示すものと思われる.

これらの試料の $\mathrm{Mg}(\mathrm{OH})_{2}$ の分解時の吸熱ピーク温度 と, 未処理試料のそれとの差をとり, 化学分析から得ら れたフッ素含有量との関係を図 6 に示した。フッ素含有 量が $0.01 \mathrm{wt} \%$ より多くなるとピークの温度差が生じ, それ以上含有量が多くなると急速に拡大するが, 含有量 が約 $6 \mathrm{wt} \%$ （0.15 HF に相当）付近になると緩やかに なっている。

ブルーサイトは，二つの $\mathrm{OH}^{-}$の密充填層の間の 6 配 位位置を $\mathrm{Mg}^{2+}$ が占める層状構造を持っている. その脱 水は Ball と Taylor $^{9)}$ によって提案された不均一脱水機 構で起こると言われている. 浜野 ${ }^{10)}$ はブルーサイトを 加熱した場合の結晶子径と格子定数の変化を検討し, こ の機構における脱水はブルーサイトの端面から始まると

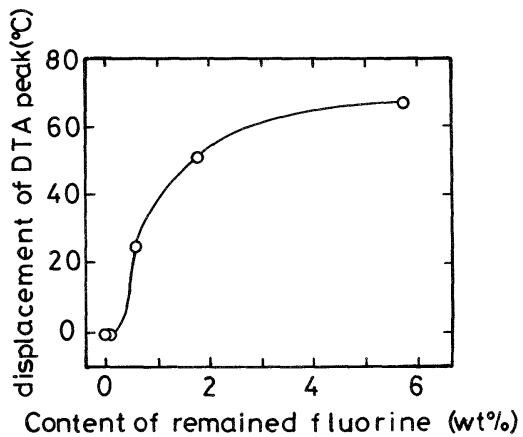

Fig.6. Content of remained fluorine and displacement of DTA endothermic peak of $\mathrm{Mg}(\mathrm{OH})_{2}$ treated with HF solution. 
報告している。前節で述べたように HF の化学吸着し た試料と無添加試料とでは, $\mathrm{Mg}(\mathrm{OH})_{2}$ の分解過程にお ける形態の変化は同様であった.この結果は $\mathrm{MgCl}_{2}$ を 添加した場合の $\mathrm{Mg}(\mathrm{OH})_{2}$ の分解過程 ${ }^{4)}$ とは異なり, 分 解が板状結晶の端面以外からは進まないことを示してい る. フッ素は元素の中で電気陰性度が最も高く, $\mathrm{Mg}$ $(\mathrm{OH})_{2}$ に対しては, 電気陰性度の差の大きい $\mathrm{Mg}^{2+}$ に選 択的に反応するものと考えられる.ブルーサイトでは, $\mathrm{Mg}^{2+}$ が結晶表面に露出している部分は端面であり, $\mathrm{HF}$ の化学吸着はこの端面の $\mathrm{Mg}^{2+}$ に対して起こるとす ると, 端面の $\mathrm{Mg}^{2+}$ に $\mathrm{HF}$ が吸着して単分子層を形成す るのに必要な数は, $\mathrm{Mg}(\mathrm{OH})_{2}\left(a_{0}=0.3147 \mathrm{~nm}, c_{0}=\right.$ $0.4769 \mathrm{~nm}$, 密度 $\left.2.37 \mathrm{~g} / \mathrm{cm}^{3}\right)$ 粒子の六角端面の長さ を $0.25 \mu \mathrm{m}, c$ 軸方向の長さを $50 \mathrm{~nm}$ として, 粒子 1 個 あたり $5.00 \times 10^{6}$ 個, $\mathrm{Mg}(\mathrm{OH})_{2} 1 \mathrm{~mol}$ では $7.57 \times 10^{20}$ 個となる. $\mathrm{HF}$ の被覆率 1 のときのフッ素含有量は $0.041 \mathrm{wt} \%$ で, これは $10^{-3} \mathrm{HF} と 0.01 \mathrm{HF}$ のフッ素含 有量の中間にあたる. $\mathrm{Mg}(\mathrm{OH})_{2}$ の分解温度の高温側へ の移行は, 図 6 より,この両者の間から始まっている. 以上の結果から, $\mathrm{Mg}(\mathrm{OH})_{2}$ 端面への $\mathrm{HF}$ の吸着層の形 成により, 熱分解が阻害されるものと考えられる.

\section{4. 総 括}

$\mathrm{Mg}(\mathrm{OH})_{2}$ の熱分解に対する $\mathrm{HF}$ の添加の影響につい て明らかになった点をまとめると次のとおりである.

（1） $700^{\circ} \mathrm{C}$ までの $\mathrm{AlF}_{3}$ の加水分解は, 水蒸気の影 響により著しく促進されたが, $\mathrm{MgF}_{2}$ の場合はほとんど 影響を受けない.

( 2) $\mathrm{AlF}_{3}$ を添加した $\mathrm{Mg}(\mathrm{OH})_{2}$ の分解ピーク温度 は, 無添加のものよりも高温側へ移動し, 添加量を 5 $\mathrm{mol} \%$ まで増やすと約 $40^{\circ} \mathrm{C}$ 高くなった. 一方, $\mathrm{MgF}_{2}$ 添加では $5 \mathrm{~mol} \%$ で $6{ }^{\circ} \mathrm{C} し$ か高くならなかった.

(3) フッ酸処理した $\mathrm{Mg}(\mathrm{OH})_{2}$ の分解ピーク温度
は, 処理濃度が $10^{-3} \mathrm{HF}$ 以下では, 変化がみられないが, これより濃度が高くなると分解温度は高温側へ移動し, 未処理試料との差は $\mathrm{Mg}(\mathrm{OH})_{2}$ と $\mathrm{HF}$ のモル比が 0.15 のとき約 $70^{\circ} \mathrm{C}$ であった.

(4) $\mathrm{HF}$ が粒子端面に化学吸着した $\mathrm{Mg}(\mathrm{OH})_{2}$ の分 解の形態は, 無添加のものと同じで, 分解が粒子端面以 外から進まないことを示している.

(5) $\mathrm{HF}$ の $\mathrm{Mg}(\mathrm{OH})_{2}$ 粒子端面への化学吸着によ り, 粒子内部からの $\mathrm{H}_{2} \mathrm{O}$ の脱離が妨害されるため, $\mathrm{Mg}$ $(\mathrm{OH})_{2}$ の分解温度は高温側へ移動する. 吸着している HF の多いほど移動量は多くなった.

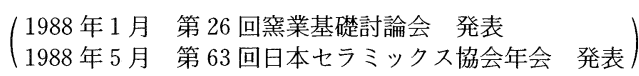

謝辞 フッ素の化学分析を快く引き受けて下さいました

（株）分析センターの佐藤 隆氏に深く感謝致します。

\section{文 献}

1）浜野健也, 室山賢治, 中川善兵衛, 斉藤勝一, 窯協, 87, 38-46 (1979).

2) K. Hamano, Z. Nakagawa and H. Watanabe, "Structure and Properties of $\mathrm{MgO}$ and $\mathrm{Al}_{2} \mathrm{O}_{3}$ Ceramics", Advances in Ceramics, Vol.10, Edited by W. D. Kingery, American Ceramic Soc., Inc. (1984) pp.610-18.

3）池上隆康, 松田伸一, 鈴木 肇, 窯協, 86, 97-101 (1978).

4) K. Hamano, O. Miikeda and Z. Nakagawa, "Sintering '87", Vol. 1, Edited by S. Sōmiya, M. Shimada, M. Yoshimura and R. Watanabe, Elsevier Applied Science (1988) pp. 79-84.

5) J. Berkowitz and J. R. Marguart., J. Chem. Phys., 37, 1853-65 (1962).

6) G. N. Gopienko., Izv. Akad. NaukSSSR, Neorg. Mater., 8, 781-82 (1972).

7) B. M. Nirsa, G. R. Allahverdov and N. P. Kozlova, $Z h$. Ohshchei Khimii, 49, 1690-93 (1979).

8) Ram. A. Sharma, J. Am. Ceram. Soc., 71, 272-66 (1988).

9) M.C. Ball and H.F.W. Taylor, Mineral. Mag. and J. Mineral. Soc., 33, 754-66 (1961).

10) K. Hamano, Yogyo-Kyokai-Shi, 74, 144-52 (1966). 